\title{
О РАЗВИТИИ ТУРИСТИЧЕСКОЙ ДИПЛОМАТИИ КИТАЯ С СОСЕДНИМИ СТРАНАМИ В ХХІ ВЕКЕ
}

\author{
ЛЮ СЯНЦЯНЬ \\ Белорусский государственный университет, \\ Минск, Республика Беларусь
}

Аннотация. Дипломатия крупной державы, соседская дипломатия, дипломатия развивающихся стран и дипломатия многосторонних международных организаций являются важными компонентами дипломатической схемы КНР.

Основные ориентиры внешней политики Китая в отношении соседних стран заключаются в следовании принципам дружественности, партнерства, добрососедства, желании поддержать безопасность и процветание стран - соседей. Автор считает, что взаимодействие Китая с соседями характеризуется сосуществованием сильных и слабых сторон, частым общением на официальном уровне и недостаточным количеством неправительственных обменов, что приводит к неполному пониманию внешней политики Китая и его намерений в странах, имеющих общую границу с Китаем.

Туристическая дипломатия интерпретируется автором как составная часть общей дипломатии Пекина, эволюционировавшая с периферии внешнеполитической деятельности на передовую и ставшая неотъемлемой частью национальной дипломатии. Рассматривается развитие туристической дипломатии Китая с Россией, Южной Кореей, Японией, Ассоциацией государств ЮгоВосточной Азии (ACEAH) в XXI в. В статье с достаточной полнотой раскрыты содержание и роль туристической дипломатии в отношениях КНР с соседними государствами, выявлены ее структурные элементы, охарактеризованы нормативная база и формы, сформулированы предложения по развитию.

Исследование основано на национальной китайской историографии, а также работах российских и западных авторов. Его базой стали документы КПК, правительства КНР, министерств и ведомств республики. Широко использованы историко-повествовательный, историко-сравнительный, институциональный, статистический методы, а также метод включенного наблюдения и анализа документов.

Материал изложен на основе системного и ценностного подходов. Обоснован вывод о том, что туристическая дипломатия способствует экономическому развитию и культурным обменам, а также достижению баланса в международных политических отношениях. Автор подчеркивает необходимость гибкого использования такого инструмента, как туризм, в условиях борьбы с пандемией COVID-19 и ее последствиями, а также призывает к глубокому обсуждению вопроса о перспективах развитии туристической дипломатии в постеэпидемическую эпоху.

Ключевые слова: туристическая дипломатия; соседская дипломатия; КНР; Россия; Южная Корея; Япония; ACEAH; пандемия COVID-19. 
Образец цитирования: Лю Сяниянь О развитии туристической дипломатии Китая с соседними странами в XXI веке // Актуальные проблемы международных отношений и глобального развития: сб. науч. ст. Минск. Вып. 9. С. 7085. https://doi.org/10.33581/2311-9470-2021-9-70-85

Введение. Китай имеет общие границы с такими могущественными государствами, как Россия, Южная Корея и Япония; в региональную организацию с большим влиянием превратилась АСЕАН, куда входят страны - соседи КНР Лаос, Мьянма, Вьетнам. В отношениях между Китаем и соседями существует множество исторически сложившихся противоречий, продолжают возникать новые. Индопакистанские отношения, китайско-индийская граница, ЮжноКитайское море, Восточно-Китайское море, Корейский полуостров эти и другие проблемы региона, по мнению международного сообщества, могут спровоцировать крупномасштабные конфликты.

После 1978 г., когда началась реализация политики реформ и открытости, КНР активно развивает туристические обмены с различными регионами и странами, особое внимание уделяя соседям. В 2013 г. Китай занял первое место в мире по числу выездных туристов, а по их расходам - второе [1, с. 156].

На Национальной рабочей конференции по туризму (январь 2015 г.) была аргументирована концепция «туристической дипломатии» [1, с. 156]. Тринадцатый пятилетний план развития туризма, опубликованный Госсоветом КНР в декабре 2016 г., призывал «полностью реализовать стратегию туристической дипломатии в новую эпоху» ${ }^{1}$, то есть развитие туризма стало рассматриваться в том числе в качестве долгосрочной цели.

Согласно статистическим данным Министерства культуры и туризма Китая, рынок внутреннего и выездного туризма в 2019 г. стабильно рос. Число внутренних туристов составило более 6 млн., что на $8,4 \%$ больше, чем в предыдущем году; число прибывающих туристов достигло 145 млн, а выезжающих - 155 млн; общий доход от туристической отрасли за год составил 6,63 трлн юаней ${ }^{2}$. Приведенная статистика подтверждает тезис о том, что китайский туризм становится важной частью мирового туризма в доэпидемическую эпоху, а

\footnotetext{
${ }^{1}$ Уведомление Госсовета КНР о выпуске «13-я пятилетки» план развития туризма // Портал китайского правительства. [Электронный ресурс]. 2020. URL: http://www.gov.cn/gongbao /content/2017/content_5160220.htm (дата обращения: 09.09.2021).

${ }^{2}$ Статистический бюллетень по развитию культуры и туризма 2019 г. // Министерство культуры и туризма КНР. [Электронный ресурс]. 2020. URL: http://zwgk.mct.gov.cn/auto255/ 202006/t20200620_872736.html?keywords (дата обращения: 24.08.2021).
} 
совокупность указанных обстоятельств стимулирует изучение его различных аспектов.

Россия, Южная Корея, Япония и участники АСЕАН имеют обширную и глубокую взаимозависимость с Китаем в политике, экономике, культуре. В силу изложенных обстоятельств цель статьи рассмотреть содержание и роль туристической дипломатии в отношениях КНР с соседними государствами и сформулировать предложения по ее развитию. Объектом исследования выступает туристическая дипломатия, предметом - развитие туристических институтов и связей Китая с Россией, Южной Кореей, Японией и государствами членами АCEAН в XXI в.

Методы исследования. Для раскрытия темы использованы следующие методы: нарративный, историко-генетический, историкосравнительный, анализа документов, описательной статистики, институциональный, терминологического анализа, включенного наблюдения. Автор руководствовался принципами историзма, системным и ценностным подходами.

Обзор литературы по теме. Основой статьи стали труды китайских, российских и западных историков, политологов, специалистовмеждународников. Внимание китайских исследователей туристической дипломатии в основном сосредоточено на изучении ее концепции и природы, взаимосвязи туризма с инициативой «Один пояс, один путь», влияния на национальный имидж, развития международного туризма. Среди них следует назвать таких авторов, как Чжан Инь [1], Мэй И [2], Чжан Цзянчи [3], Ма Юцзюнь [4], Ван Пэнфэй [5].

Российские ученые концентрируют внимание на истории развития туристических взаимосвязей, формах обменов и их значении для российско-китайских отношений. Это работы М.В. Ефремова [6], Л.А. Можаева [7], Т.В. Черевичко [8].

Исследования западных экспертов направлены на характеристику атрибутов туризма, среди которых прежде всего мирный характер и уязвимость. S. Becken (С. Беккен) [8] и S. Kim (C. Ким) [9] подчеркивают важный вклад туризма в построение мирных международных отношений. T. S. Tse (T. C. Теcc) [10] доказывает, что туризм усиливает мягкую силу государства и снижает степень конфликтности. A. Deep (А. Дипп) [11] и O. Paik (О. Пайк) [12] скептически относятся к влиянию туристической дипломатии на международную жизнь.

Китайские и зарубежные ученые обсуждают коннотацию, функции, содержание, направления и формы туристической дипломатии 
КНР, а также исследуют историю ее развития, потенциал и значение.

Результаты исследования. Туризм как канал культурного обмена и взаимопонимания играет очень важную роль в укреплении отношений Китая и России. Важной вехой в их развитии стало учреждение в 2000 г. на уровне вице-премьеров Комитета китайскороссийского сотрудничества в области образования, культуры, здравоохранения и спорта (в 2007 г. переименован в Комитет китайскороссийского гуманитарного сотрудничества); в его рамках осуществлялись регулярные встречи премьер-министров ${ }^{3}$. В 2001 г. Комитет учредил Рабочую группу по китайско-российскому сотрудничеству в области туризма ${ }^{3}$.

Китай и Россия совместно провели «Год страны» (2006 2007 гг.), в рамках которого состоялось более 500 мероприятий, углубивших взаимное политическое доверие и способствовавших практическому сотрудничеству в туристической отрасли. 2009 и 2010 годы были объявлены «Годом языка» с участием деятелей образования и культуры [6, с. 1130]. 2012 и 2013 годы вошли в историю китайскороссийских отношений как «Год туризма» [6, с. 1130], причем Россия стала пионером в инициировании новой модели поддержки национальной дипломатии туристической деятельностью.

В мае 2015 г. в Москве было подписано «Совместное заявление Российской Федерации и Китайской Народной Республики о сотрудничестве по сопряжению строительства Евразийского экономического союза и Экономического пояса Шелкового пути», в котором сформулирован новый стратегический план развития двусторонних отношений. Президент России В.В. Путин выразил мнение, что Евразийский экономический союз и проект «Экономический пояс Шелкового пути» могут гармонично дополнять друг друга. В октябре того же года на 16-м заседании Китайско-российского комитета по гуманитарному сотрудничеству был подписан «Меморандум о расширении сотрудничества в сфере туризма» ${ }^{4}$, а в декабре премьер-министр Госсовета Ли Кэцян и премьер-министр Российской Федерации Д. А. Медведев подписали «Совместное коммюнике», в котором выразили поддержку

\footnotetext{
${ }^{3}$ Китайско-российское гуманитарное сотрудничество открывает новый этап // Портал китайского правительства. [Электронный ресурс]. 2007. URL: http://www.gov.cn/jrzg/2007-09/02/ content_734478.htm (дата обращения: 08.09.2021).

${ }^{4}$ В Сиане состоялось 16-е заседание комитета китайско-российского гуманитарного сотрудничества // Портал китайского правительства. [Электронный ресурс]. 2015. URL: http://www. gov.cn/xinwen/2015-10/09/content_2944469.htm (дата обращения: 25.08.2021).
} 
развитию сотрудничества в сфере туризма ${ }^{5}$.

В июне 2016 г. в «Совместном заявлении Китайской Народной Республики и Российской Федерации» содержался призыв «всесторонне продвигать сотрудничество в сферах туризма, образования и культуры через официальные и неправительственные каналы», «сосредоточиться на успешном проведении Года китайско-российских медиа обменов» ${ }^{6}$ (2016-2017 гг.). Медиа-обмены способствовали двум народам «по-настоящему понять современную Россию» и «современный Китай». Пекин и Москва организовали более 250 проектов сотрудничества, направленных на эффективную рекламу туризма ${ }^{7}$.

В 2018 и 2019 гг. активизировались региональные сотрудничество и обмены. В 2019 г. число китайских туристов в России достигло 1,88 млн человек; число российских туристов в Китае - 2,72 млн, что в сумме превысило 4 млн 8

В последние годы Пекином и Москвой формируются несколько платформ и структур (Конференция министров туризма, Рабочая координационная группа по туризму, Комитет китайско-российского гуманитарного сотрудничества), призванных повысить эффективность двустороннего взаимодействия в этой области; результаты и перспективы сотрудничества формулируются в меморандумах и совместных заявлениях.

КНР и Япония являются соседями с общей давней историей и глубокими отношениями, которые претерпели как позитивные изменения, так и конфронтацию. В период образования «нового Китая» Пекин был изолирован от западных стран. Правительства Китая и Японии достигли нормализации отношений в 1972 г., а спустя шесть лет подписали Договор о мире и дружбе.

В 1984 г. 3000 молодых людей, представители всех слоев японского общества, были приглашены посетить Китай, что автор оцени-

\footnotetext{
${ }^{5}$ Совместное коммюнике 20-й очередной встречи премьер-министров Китая и России // Министерство иностранных дел КНР. [Электронный ресурс]. 2015. URL: https://www.fmprc.gov. cn/web/gjhdq_676201/gj_676203/oz_678770/1206_679110/1207_679122/t1325537.shtml (дата обращения: 08.09.2021).

${ }^{6}$ Совместное заявление Китайской Народной Республики и Российской Федерации (полный текст) // Портал китайского правительства. [Электронный ресурс]. 2016. URL: http://www.gov.cn/xinwen/2016-06/26/content_5085559.htm (дата обращения: 27.08.2021).

${ }^{7}$ Китайские и российские СМИ отмечают открытие «Года китайско-российских медиа-обменов» // Синьхуа. [Электронный ресурс]. 2016. URL: http://www.xinhuanet.com/world/201601/23/c_1117872191.htm (дата обращения: 27.08.2021).

8 Федеральная служба государственной статистики [Электронный ресурс]. 2021. URL: https://gks.ru/folder/23457 (дата обращения: 09.09.2021).
} 
вает как первое масштабное мероприятие по взаимодействию Токио с Пекином. В 1985 г. 500 граждан Китая посетили Японию по линии Обществ дружбы ${ }^{9}$. Туристическая дипломатия, таким образом, осуществлялась прежде всего в форме взаимных визитов молодежи, которые способствовали активизации взаимопонимания и дружбы.

После вступления в XXI в. оба правительства продемонстрировали позитивное отношение к улучшению дружественных отношений и активно продвигали сочетание официальных и неправительственных обменов. В 2000 г. 5 тыс. представителей японских неправительственных организаций посетили Китай, а в 2002 г., чтобы отметить 30-ю годовщину нормализации дипломатических отношений между Китаем и Японией, более 13 тыс. граждан Японии собрались в Пекине $^{10}$. Государственные структуры руководили организацией и проведением таких мероприятий, как «Конференция по развитию обменов в сфере туризма между Китаем и Японией» (2005 г.), «Выставка обмена туристическими ресурсами между Китаем и Японией», «Год китайско-японских обменов в сфере туризма», «Форум по развитию туризма в Китае и Японии» (2006 г.) ${ }^{11}$.

В 2011 г. правительство Японии смягчило индивидуальную туристическую визовую политику, что привело к росту поездок [14, с. 113], который был прерван спорами об островах Дяоюйдао, участии Японии во Второй мировой войне и интерпретации авторами учебников китайско-японских отношений. Многие потенциальные китайские туристы отказались ехать в Японию в 2014 г. [15, с. 1], однако уже в мае следующего года более 3000 японцев, представителей различных слоев, побывали в Китае. Это масштабное событие является ярким подтверждением, что основа китайско-японской дружбы заложена в истории отношений между народами. Председатель КНР Си Цзиньпин приветствовал и высоко оценил указанную поездку ${ }^{12}$.

\footnotetext{
${ }^{9}$ Обмены между китайской и японской молодежью с 1984 года: вечная дружба между Китаем и Японией // Портал китайского правительства. [Электронный ресурс]. 2017. URL: http://www.gov.cn/jrzg/2007-06/17/content_651190.htm (дата обращения: 15.08.2021).

${ }^{10}$ В Пекине прошла встреча дружбы, посвященная 30-летию нормализации дипломатических отношений между Китаем и Японией // Посольство КНР в Российской Федерации. [Электронный ресурс]. 2017. URL: http://ru.china-embassy.org/chn/xwdt/t73652.htm (дата обращения: 09.09.2021).

11 Торжественное открытие выставка обмена туристическими ресурсами между Китаем и Японией в Токио // Портал китайского правительства. [Электронный ресурс]. 2006. URL: http://www.gov.cn/zwjw/2006-03/13/content_226376.htm (дата обращения: 09.09.2021).

12 Председатель КНР Си Цзиньпин выступил с важной речью на конгрессе по дружбе и обме ну между Китаем и Японией // Жэньминь жибао. [Электронный ресурс]. 2015. URL: http://cpc .people.com.cn/n/2015/0524/c64094-27046720.html (дата обращения: 09.09.2021).
} 
В ноябре 2016 г. Китай и Япония подписали «Меморандум о взаимопонимании по укреплению туристического обмена и сотрудничества» ${ }^{13}$. Для развития туристических обменов было организовано совместное мероприятие «Праздник Луны» (2017 г.). Премьер Госсовета КНР Ли Кэцян при Японии во время визита в Японию, состоявшегося в 2018 г. после восьмилетнего перерыва, призвал поощрять неправительственные обмены для содействия развитию официальных контактов и укреплять двустороннее сотрудничество в области культуры и туризма.

Впоследствии 2019 год был объявлен «Годом поощрения молодежного обмена», в то время как число китайских туристов в Японии достигло 9,6 млн. В условиях COVID-19 КНР и Япония оказывали друг другу взаимную поддержку, что способствовало углублению дружеских отношений китайского и японского народов на ментальном уровне [16, с. 29].

КНР и Республика Корея имеют тесные культурные связи и общие интересы. Председатель КНР Си Цзиньпин особо отмечает, что они являются естественными партнерами. По его оценке, «дружеские обмены и взаимовыгодное сотрудничество всегда являются основной темой китайско-южнокорейских отношений». ${ }^{15}$

Во время холодной войны между двумя странами Пекин и Токио уклонялись от обменов визитами на государственном уровне, изредка позволяя это лишь представителям неправительственных организаций. В результате официального визита президента США Р. Никсона в Китай, установления дипломатических отношений между Китаем и Японией и начала диалога Север - Юг на Корейском полуострове, а также других изменений в международной ситуации отношения Китая и Южной Кореи начали меняться.

В 1980-е гг. корейцы, проживающие в Северо-Восточном Китае, получили возможность посещать родственников в Южной Корее [17, с. 69]. В 1994 г. Республика Корея сняла ограничения на поездки в

\footnotetext{
${ }^{13}$ Китай и Япония подписывают меморандум о дальнейшем укреплении туристических обменов и сотрудничества // Портал китайского правительства. [Электронный ресурс]. 2016. URL: http://www.gov.cn/xinwen/2016-11/25/content 5137482.htm (дата обращения: 26.08.2021).

${ }^{14}$ Пусть снова восторжествует дело мира и дружбы между Китаем и Японией, ВестникГоссо вета, 2018 № 18 // Портал китайского правительства. [Электронный ресурс]. 2018. URL: http:/ /www.gov.cn.qingcdn.com/gongbao/content/2018/content_5301805.htm (дата обращения: 29.08 .2 021).

${ }^{15}$ Си Цзиньпин встретился с президентом Южной Кореи Мун Чжэ Ином // Портал китайского правительства. [Электронный ресурс]. 2018. URL: http://www.gov.cn/xinwen/2017-11/12/ content_5238990.htm (дата обращения: 19.08.2021).
} 
Китай. В мае 1998 г. правительство Китая включило PК в ADS (Approved Destination Status), что означало получение гражданами Китая права путешествовать в РК за свой счет ${ }^{16}$. В XXI в. южнокорейское правительство стало практиковать запуск специальных туристических продуктов, в связи с чем количество обменов между людьми быстро возросло.

Подчеркнем, что первый в мире Институт Конфуция и первый Китайский культурный центр в Азии были созданы именно в Сеуле [18, с. 140]. Проведение «Года визита в Китай» (2010 г.), развитие сети дружественных городов, более низкие визовые пороги свидетельствуют, что китайско-южнокорейская туристическая дипломатия вступила в этап быстрого роста ${ }^{17}$. В 2014 г. председатель КНР Си Цзиньпин посетил РК с официальным визитом. Си Цзиньпин и президент Южной Кореи Пак Кын Хе объявили 2015 и 2016 гг. «Годом туризма Китая» и «Годом туризма Кореи» соответственно. В рамках «Года китайского туризма» было проведено более 120 мероприятий по обмену туристами, в которых активное участие приняли государственные структуры. В 2016 г. число китайских туристов в РК достигло 8,07 млн, составив $47 \%$ от общего числа въезжающих туристов, а 4,76 млн южнокорейских туристов посетили Китай ${ }^{18}$.

Китайско-южнокорейские отношения значительно осложнил «Инцидент THAAD» (февраль 2017 г.) ${ }^{19}$. Государственное управление по делам туризма Китая (в 2018 г. переименовано в Министерство культуры и туризма КНР) в этой связи выпустило «Предупреждение о поездках в Южную Корею» ${ }^{20}$. Размещение противоракетного комплекса наземного базирования THAAD, по оценке события Пекином, серьезно подрывает региональный стратегический баланс, наносит серьезный ущерб интересам национальной стратегической безопасности Китая и вызывает серьезное недовольство китайского народа.

\footnotetext{
${ }^{16}$ Отношения между Китаем и Южной Кореей // Сайт новостей Китая. [Электронный ресурс] . 2011. URL: http//www.chinanews.com/gn/2011/05-19/3053480.shtml (дата обращения: 09.09.2021).

${ }^{17}$ Основные моменты китайско-корейских отношений в 2010 г. // Министерства иностранных дел КНР. [Электронный ресурс]. 2010. URL: https:/www.fmprc.gov.cn/web/gihdq_676201gj_ 676203/yz_676205/1206_676524/ywfc_676546/t782862.shtml (дата обращения: 09.09.2021).

${ }^{18}$ Korea National Tourism Organization [Electronic resource]. 2017. URL: http://kto.visitkorea.or.kr/kor.kto (accessed: 20.08.2021).

${ }^{19}$ Theater High Altitude Area Defense - противоракетный комплекс подвижного наземного баз ирования для высотного заатмосферного перехвата ракет средней дальности.

${ }^{20}$ Советы путешественникам в Южную Корею // Министерство культуры и туризма КНР. [Э лектронный ресурс]. 2017. URL: https://www.mct.gov.cn/ggfw/cxts/201703/t20170303_832101.h tm (дата обращения: 06.09.2021).
} 
Граждане Китая добровольно бойкотировали корейские товары и отказались от поездок в Южную Корею. Число въезжающих в Южную Корею туристов в 2017 г. снизилось на 23\% по сравнению с предыдущим годом. Численность китайских туристов в Южной Корее сократилось до 4,17 млн (на 48\%), а южнокорейских туристов в Китае - до $3,87$ млн (на $19 \%)^{18}$.

Вклад в «потепление» отношений и развитие неправительственных обменов между двумя странами внесла туристическая фотовыставка, организованная в апреле 2018 г. Представительством Китая по туризму в Сеуле и правительством южнокорейской столицы ${ }^{21}$. Это мероприятие следует рассматривать как интерактивную модель сотрудничества государственных структур и предпринимателей, значительно повышающую эффективность туристической дипломатии. В августе Шанхай разрешил туристическим группам поехать в РК, и туристические обмены начали возвращаться в нормальное состояние.

Хотя отношения между Пекином и Сеулом постепенно возвращаются в позитивную «эпоху после THAAD», однако компенсации достигнутого до инцидента уровня в экономике, туризме, культурном сотрудничестве не произошло. В мае 2019 г. в Пекине прошла конференция министров туризма Китая и Кореи ${ }^{22}$, в августе того же года в Инчхоне состоялась 9-я встреча министров туризма Китая, Японии и Кореи $^{23}$. Две встречи на уровне министров туризма были проведены в течение года. Эти события свидетельствуют о достаточно важной роли туризма в двусторонних отношениях Китая и Республики Корея.

Ассоциация государств Юго-Восточной Азии $(\boldsymbol{A C E A H})$ - добрый сосед, хороший друг и надежный партнер Китая. Китайский выездной туризм берет начало именно со стран АСЕАН. В 1988 г. Государственный совет КНР разрешил китайским гражданам навестить родственников в Таиланде, а позже - в Сингапуре и Малайзии. В конце XX в. избранными направлениями для китайских путешественни-

\footnotetext{
${ }^{21}$ Китайско-корейская туристическая фотовыставка 2018 прошла в Сеуле // Синьхуа. [Электр онный ресурс]. 2017. URL: http://www.xinhuanet.com/overseas/2018-04/25/c_129858937.htm (да та обращения: 06.09.2021).

22 Ло Шуган встретился с министром культуры, спорта и туризма Кореи Парк Янъюй // Мини стерство культуры и туризма КНР. [Электронный ресурс]. 2017. URL: https://www.mct.gov.cn/ whzx/whyw/201905/t20190531_844046.htm (дата обращения: 09.09.2021).

${ }^{23}$ Состоялась 9-я встреча министров туризма Китая, Японии и Южной Кореи // Синьхуа. [Электронный ресурс]. 2017. URL: http://www.xinhuanet.com/2019-08/30/c_1124943640.htm (дата обращения: 09.09.2021).
} 
ков становятся Филиппины, Камбоджа, Вьетнам, Лаос, Бруней ${ }^{24}$.

В ноябре 2004 г. состоялась 1-я ярмарка Китай - АСЕАН, сопровождавшаяся туристической выставочной площадкой. 2006 год КНР и страны АСЕАН объявили «Годом дружбы и сотрудничества», в ходе которого состоялись правительственные семинары высокого уровня, участники которых обосновали необходимость углубления сотрудничества в сфере туризма; в целях интенсификации негосударственного туристического обмена состоялась Конференция по обмену туристами между Китаем и $\mathrm{ACEAH}^{25}$. В ноябре 2009 г. в г. Куньмин (провинция Юньнань) был организован первый Форум сотрудничества Китая и АСЕАН в туристической отрасли с выделением правительственных, корпоративных и академических сессий, что значительно повысило эффективность его работы ${ }^{26}$.

Подчеркнем влияние состояния двусторонних политических отношений на туристические обмены. Проблема Южно-Китайского моря по-прежнему вызывает споры между Китаем и такими участниками АСЕАН, как Вьетнам, Филиппины, Малайзия и Бруней. Сотрудничество в сфере туризма стало важным способом диалога, предоставляя возможность для улучшения двусторонних отношений. Выдвинутая председателем КНР Си Цзиньпином в 2013 г. инициатива «Один пояс, один путь» предполагает новые перспективы сотрудничества между Китаем и странами АСЕАН, стимулирует рост культурных и академических обменов, а также туристических услуг.

2017 год был объявлен Годом туристического сотрудничества Китая и АСЕАН, в течение которого проводился ряд мероприятий по обмену туристами, прежде всего в учебно-ознакомительных и профессиональных целях. Далее в ноябре 2018 г. КНР и АСЕАН приняли документ под названием «Видение стратегического партнерства Китая и АСЕАН на период до 2030 года», который предусматривает создание официального «механизма сотрудничества на высоком уровне для укрепления, углубления и расширения двустороннего сотрудни-

\footnotetext{
24 Добавлена Камбоджа и другие страны как страна назначения для самофинансирования поездок за границей // Сина. [Электронный ресурс]. 2000. URL: http://news.sina.com.cn/ society/2000-09-14/127114.html (дата обращения: 09.09.2021).

${ }^{25}$ В Камбодже прошла 11-я Конференция дружбы народов Китая и АСЕАН // Синьхуа. [Электронный ресурс]. 2017. URL: http://www.xinhuanet.com//world/2017-08/07/c_112 1445586.htm (дата обращения: 13.01.2021).

${ }^{26}$ Форум сотрудничества в области туризма между Китаем и АСЕАН прошел в Куньмине 19го числа // China Daily. [Электронный ресурс]. 2009. URL: https://www.chinadaily.com.cn/zgzx/ 2009-11/19/content_9002214.htm (дата обращения: 09.09.2021).
} 
чества в сфере туризма» ${ }^{27}$.

На Встрече лидеров Китая и АСЕАН в ноябре 2019 г. было выпущено «Совместное заявление», в котором инициатива «Один пояс, один путь» увязывалась с документом «Взаимосвязанность АСЕАН $2025 »^{28}$. Этот документ стал основой для дальнейшего развития сотрудничества в сфере туризма. Впоследствии 2019 год был объявлен «Годом туризма Китая и Лаоса» ${ }^{29}$ и «Годом культурного туризма Китая и Камбоджи» ${ }^{30}$.

В ноябре 2020 г. Китай, 10 стран ACЕАН, а также Япония, Южная Корея, Австралия и Новая Зеландия подписали Соглашение о всестороннем региональном экономическом партнерстве (ВРЭП), что будет способствовать восстановлению государств - участников после пандемии, в том числе и туристической отрасли ${ }^{31}$.

По оценке автора, отношения Китая и АСЕАН превратились в наиболее успешную и динамичную модель сотрудничества в Азиатско-Тихоокеанском регионе и образец построения «Сообщества единой судьбы человечества». Туристическая дипломатия является важной компонентой отношений Китая и Ассоциации и имеет внушительное торговое пространство.

Обсуждение полученных результатов. Анализ развития туристической дипломатии КНР с Россией, Южной Кореей, Японией, странами АСЕАН подтверждает, что туризм играет важную роль во взаимодействии с соседними странами и создает благоприятную окружающую среду для развития Китая в различных сферах.

Туристическая дипломатия способствует экономическому развитию, в частности, способствует росту валютного дохода. Число двусторонних обменов между Китаем и Россией превысило 4 млн в 2018

\footnotetext{
${ }^{27}$ Видение стратегического партнерства Китая и АСЕАН до 2030 года // Синьхуа. [Электронный ресурс]. 2018. URL: http://www.xinhuanet.com/world/2018-11/15/c_1123718487.htm (дата обращения: 07.09.2021).

28 Придать новый импульс «повышению качества» Китая и АСЕАН // Портал китайского правительства. [Электронный ресурс]. 2019. URL: http://www.gov.cn/xinwen/201911/08/content_5450286.htm (дата обращения: 28.08.2021).

${ }^{29}$ Успешно завершился «Год туризма Китая и Лаоса» // Министерство культуры и туризма KНР. [Электронный ресурс]. 2019. URL: https:/www.mct.gov.cn/whzx/whyw/201912/ t20191217_849623.htm (дата обращения: 09.09.2021).

30 «Год культурного туризма Китая и Камбоджи» открывается в Камбодже // Министерство культуры и туризма КНР. [Электронный ресурс]. 2019. URL: https://www.mct.gov.cn/whzx/ whyw/201901/t20190131_837162.htm (дата обращения: 09.09.2021).

${ }^{31}$ Подписание ВРЭП: победа свободной торговли, возможность регионального процветания // Портал китайского правительства. [Электронный ресурс]. 2019. URL: http://www.gov.cn/ xinwen/2020-11/17/content_5561955.htm. (дата обращения: 09.09.2021).
} 
г., Китаем и РК - 9 млн, Китаем и Японией - 11 млн, Китаем и ACEАН - 50 млн. В 2010 г. доход от въездного туризма составил 45,8 млрд долл. США, а в 2019 г. увеличился до 131,3 млрд долл. [19, с. 224].

Туризм сопровождается культурным обменом, стимулирует связи между народами. Мероприятия в рамках Года туризма, инициированные правительствами, а также Год поощрения молодежного обмена, Конференция по обмену туристами между Китаем и АСЕАН, учреждение Комитета китайско-российского гуманитарного сотрудничества и другие события, состоявшиеся по инициативе или с участием не только государственных структур, но и международных организаций, в том числе неправительственных, а также предприятий и даже отдельных лиц продвигают культуру стран - партнеров и направлены на укрепление культурных обменов, способствующих углублению понимания народами друг друга и преодолению чувства враждебности. Туристическая дипломатия способна вносить баланс в двусторонние отношения в условиях, когда классическая дипломатия находится в затруднительном положении (в качестве примера в статье приводится инцидент THAAD 2017 г.).

В условиях глобальной пандемии COVID-19, по данным Bceмирной туристской организации, в 2020 г. число международных туристов во всем мире сократилось на 74\% по сравнению с 2019 г. $^{32}$ Изза неопределенности многие страны ввели строгие ограничения на въезд, включая такие меры, как обязательное тестирование, карантин и закрытие границ. Многие эксперты считают, что полное восстановление мировой туристической индустрии ожидается к 2023 г. $^{32}$ Одним из проявлений пандемии стало то, что международный туризм на многих направлениях практически остановился, а туристическая дипломатия утратила свою первоначальную функцию.

Заключение. Вопрос о том, имеет ли туристическая дипломатия собственное значение, стал предметом для научных дискуссий. Автор считает, что влияние пандемии недолговечно и «подавленный» выездной туризм неизбежно получит «взрывной» рост. Восстановление внутреннего туризма Китая подтверждает это предположение. Китай принял серьезные меры социальной профилактики и контроля, эффективно контролируя распространение вируса на материке, и индустрия туризма быстро вернулась к уровню, зафиксированному до начала пандемии. Эффективный контроль над глобальной эпидемией,

\footnotetext{
${ }^{32}$ International tourism and COVID-19 [Electronic resource]. 2021. URL: https://www.unwto.org/i nternational-tourism-and-covid-19 (accessed: 25.08.2021).
} 
уровень вакцинации и восстановление международных рейсов являются ключом к восстановлению международного туризма. Когда страна рассматривает возможность возобновления туристического обмена с другой страной, учитывается не только эпидемическая ситуация, но и геополитические отношения, которые также являются важным фактором.

Автор считает, что необходимо формировать многоуровневую платформу обмена, разрабатывать соглашения о сотрудничестве в сфере туризма, увеличивать количество международных рейсов, чтобы ускорить перемещение персонала, делиться опытом восстановления и развития туризма, особенно посредством обмена научными достижениями и технологиями, улучшать использование возможностей по предотвращению и управлению эпидемиями, совершенствовать строительство инфраструктуры и помощь слаборазвитым районам в восстановлении туристической индустрии. Развитие туристической дипломатии в условиях кризиса стимулирует межгосударственные отношения в выгодном для КНР направлении. По мнению автора, такая проблема как восстановление и пути развития межгосударственного туризма в постэпидемическую эпоху остро нуждается в более глубоком обсуждении.

\section{Библиографические ссылки}

1. Чжсан Инь Синь ши дай да го тэ се вай цзяо ши е ся лу ю вай цзяо янь цзю (Исследования туристической дипломатии с точки зрения дипломатии крупных держав в новую эру) // Идеологический фронт. 2018. № 4. С. 162-170.

2. Мэй И. Лу ю вай цзяо ю чжун го хэ пин фа чжань (Туристическая дипломатия и мирное развитие Китая): дис. ...канд. / Мэй И, 2006. 43 л.

3. Чжан Цзянчи, Се Чаоу «И дай и лу» чанг и ся чжун го - дун мэн лу ю чан е хэ цзо: чжи сян, цзе гоу ю лу цзин (Сотрудничество Китая и АСЕАН в сфере туризма в рамках инициативы «Один пояс, один путь»: направление, структура и путь) // Журнал Университета Хуацяо. - 2020. № 2. C. 25-34.

4. Ма Юизюнь Чжун ру минь цзянь вай цзяо фа чжань де си лу ю дуй це янь цзю (Исследование мыслей и мер противодействия развитию китайско-российской неправительственной дипломатии) // Сибирские исследования. 2017. Т. 44, № 6. С. 9-11.

5. Ван Пэнфэй Лу ю вай цзяо ю гоу цзянь во го синь тип го цзя гуань си вэнь ти тан си (Туристическая дипломатия и построение нового типа государственных отношений в Китае) // Современная наука управления. 2017. № 12. С. 109-111.

6. Ефремова М. В., Чкалова О. В., Би Жуй Анализ развития международного туризма между Россией и Китаем // Экон. анализ: теория и практика. 2017. Т. 16. № 6. С. 1127-1139.

7. Можаева Л. А. Пространство народной дипломатии: туризм // Россия и соврем. мир. 2019. № 2. C. 243-250.

8. Черевичк T. В. Туризм как инструмент публичной дипломатии // Изв. Сарат. ун-та. Н. С. Сер.: История. Междунар. отношения. 2014. Т. 14, № 4. С. 93-95.

9. Becken S., Carmignani F. Does tourism lead to peace? Annals of Tourism Research, 2016, No. 61. P. 63-79. 
10. Kim S. S., Prideaux B., Prideaux J. Using tourism to promote peace on the Korean Peninsula. Annals of Tourism Research. 2007. Vol. 34, No. 2, p. 291-309.

11. Tse T. S. Chinese outbound tourism as a form of diplomacy. In: Tourism Planning \& Development. 2013. Vol. 10, No. 2, p. 149-158.

12. Deep A., Johnston C. S. Travel advisories - destabilising diplomacy indisguise, Leisure and Events, 2017, Vol. 9, No. 1, p. 82-99.

13. Paik O. The politics of Chinese tourism in South Korea: political economy, state-society relations, and international security. In: The Pacific Review, 2019. Vol. 33. No. 2, p. 331-355.

14. Джин Юши Чжун го да лу ю кэ де фу ри лу ю хо дун конг цзянь ге цзюй (Пространственная структура туристических действий материковых китайских туристов в Японию) // Мировая география исследований. 2017. Т. 26, № 2. С. 110-118.

15. Кан Ченгвен Дяо ю дао чжэн дуань дуй чжун ри лян го цзин цзи гуань департамент де ин сян фэнь си (Анализ влияния разногласий Дяоюйдао на экономических отношениях между Китаем и Японией) // Японские исследования. 2014. № 2. С. 1-15.

16. Гао Хун Ри бен де синь гуань фэй янь ю цин ин дуй цзи ци дуй чжун ри гуань си де ин сян (Ответ Японии на пандемию COVID-19 и ее влияние на китайско-японские отношения) // Японский журнал. 2020. № 2. С. 27-32.

17. Линь Шенгай Гай ге кай фан чжи чу чжун го дуй хань го «лю гуань минь фэнь ли» чжэн це чу тан (Предварительное исследование политики Китая по «отделению чиновников от народа» в Корее в начале реформ и открытости) // Исследования по современной истории Китая. 2014. № 2. С. 68-73.

18. Лю Тинтин Цянь си конг цзы сюэ юань гун гун вай цзяо чжи ненг (Краткий анализ публичной дипломатической функции институтов Конфуция) // Реформа и открытие. 2017. № 22. C. $139-140$.

19. Ежегодник по статистике в сфере культуры и туризма в Китае // Министерство культуры и туризма КНР. Пекин: Национальная библиотечная пресса, 2020. С. 224.

Дата поступления статьи: 10.09.2021.

Автор: Лю Сянцянь - аспирант кафедры международных отношений Белорусского государственного университета (Минск, Республика Беларусь); e-mail: liuxiangqian2016@gmail.com.

\title{
STUDY ON THE DEVELOPMENT OF CHINA'S TOURISM DIPLOMACY WITH NEIGHBORING COUNTRIES IN THE 21ST CENTURY
}

\author{
LIU XIANGQIAN \\ Belarusian State University, Minsk, Republic of Belarus
}

\begin{abstract}
Major country diplomacy, neighboring diplomacy, developing country diplomacy, and multilateral international organization diplomacy are important components of China's diplomatic layout. China's neighboring diplomacy is to deepen relations with neighboring countries in accordance with the concept of friendship, sincerity, benefit and tolerance, and the diplomatic policy of being kind to and partnering with neighbors. The author believes that China's exchange with its neighbors is characterized by the coexistence of strengths and weaknesses, frequent contacts at the official level and an insufficient number of non-governmental exchanges, which
\end{abstract}


leads to an incomplete understanding of China's foreign policy and its intentions in countries with a common border.

Tourism diplomacy is interpreted by the author as an integral part of the general diplomacy of Beijing, which has evolved from the periphery of foreign policy to the front line and has become an important part of national diplomacy. This article reviewed the development of China's tourism diplomacy with Russia, South Korea, Japan, and the Association of Southeast Asian Nations (ASEAN) in the 21st century. The article fully and completely reveals the content and role of tourism diplomacy in the relations between China and neighboring countries, determines the structural elements, framework and form of tourism diplomacy, and puts forward development suggestions.

The study is based on national Chinese historiography, as well as the works of Russian and Western authors. Its source is based on the documents of the Chinese Communist Party, the government of the People's Republic of China, and various ministries and commissions of the Republic. Historical narrative, historical comparison, system, statistics, observation and analysis methods are widely used. The material is presented on the basis of a systemic and value-based approach. Researches show that tourism as an effective means can promote economic development, promote cultural exchanges, and balance bilateral relations in the process of interacting with neighboring countries. The author emphasizes that the global pandemic of COVID-19 has accelerated the evolution of the world's major changes, and it is necessary to use tourism diplomacy flexibly to respond to changes in the international environment. There is an urgent need for a more in-depth discussion on how to carry out tourism diplomacy in the post-coronavirus world.

Key words: tourism diplomacy; neighboring diplomacy; China; Russia; South Korea; Japan; ASEAN; COVID-19.

For citations: Liu Xiangqian (2021). O razvitii turisticheskoj diplomatii Kitaja s sosednimi stranami v XXI veke [Study on the development of China's tourism diplomacy with neighboring countries in the 21 st century]. In: Actual problems of international relations and global development: collection of scientific papers. Minsk. Vol. 9, p. 70-85. https://doi.org/10.33581/2311-9470-2021-9-70-85

\section{References}

1. Zhang Ying (2018). Xin shi dai da guo te se wai jiao shi ye xia lv you wai jiao yan jiu [Research on Tourism Diplomacy from the Perspective of the Diplomacy of Major Powers in the New Era]. In: Ideological front. Vol. 4. P. 162-170. (In Chin.)

2. Mei Y. (2006). Lv you wai jiao yu zhong guo he ping fa zhan [Tourism Diplomacy and China's Peaceful Development]. In: Wu han da xue, 43 p. (In Chin.)

3. Zhang Chijiang, Xie Chaowu. (2020). "Yi dai yi lu" chang yi xia zhong guo - dong meng chan ye he zuo: zhi xiang, jie gou, yu lu jing [China-ASEAN Tourism Industry Cooperation under the "One Belt and One Road" Initiative: Direction, Structure and Path]. In: Hua qiao da xие хие bao. Vol. 2. P. 25-34. (In Chin.)

4. Ma' Youjun (2017). Zhong e min jian wai jiao de fa zhan si lu yu dui hua zheng ce yan jiu [Research on Thoughts and Countermeasures of the Development of China-Russia Civil Diplomacy]. In: Xi bo li ya yan jiu. Vol. 6. P. 9-11. (In Chin.) 
5. Wang' Pengfei (2017). Lv you wai jiao yu gou jian wo guo xin xing guo jia guan xi wen ti tan xi [An Analysis of Tourism Diplomacy and the Construction of my country's New Type of State Relations]. In: Xian dai guan li ke xue. Vol. 12. P. 109-111. (In Chin.)

6. Efremova M. V. (2017). Analiz razvitija mezhdunarodnogo turizma mezhdu Rossiej i Kitaem [Analysis of the development of international tourism between Russia and China]. In: Econ. analysis: theory and practice. No. 6. P. 1127-1139. (In Russ.)

7. Mozhaeva L. A. (2019). Prostranstvo narodnoj diplomatii: turizm [People's diplomacy space: tourism]. In: Russia and the modern world. No. 2. P. 243-250. (In Russ.).

8. Cherevichko T. V. (2014). Turizm kak instrument publichnoj diplomatii [Tourism as a tool of public diplomacy]. In: History of International Relations. No. 4. P. 93-95. (In Russ.)

9. Becken S. (2016). Does tourism lead to peace? In: Annals of Tourism Research. No. 61. P. 63-79. 10. Kim S. S., Prideaux B., Prideaux J. (2007). Using tourism to promote peace on the Korean Peninsula. In: Annals of Tourism Research. Vol. 34. No. 2. p. 291-309.

11. Tse T. S. (2013). Chinese outbound tourism as a form of diplomacy. In: Tourism Planning \& Development. Vol. 10. No. 2. p. 149-158.

12. Deep A., Johnston C. S. (2017). Travel advisories - destabilising diplomacy in disguise. In: Leisure and Events. Vol. 9. No. 1. P. 82-99.

13. Paik O. (2019). The politics of Chinese tourism in South Korea: political economy, state-society relations, and international security. In: The Pacific Review. Vol. 33. No. 2. P. 331-355.

14. Jin Yushi. (2017). Zhong guo da lu you ke de fu ri lv you kong jian ge ju [The Spatial Pattern of Tourist Activities in Japan for Mainland Chinese Tourists]. In: World geography of research. Vol. 2. P. 110-118. (In Chin.)

15. Kang Chengwen (2014). Diao yu dao zheng duan dui zhong ri liang guo jing ji guan xi de ying xiang fen xi [Analysis of the Influence of the Diaoyu Islands Dispute on the Economic Relations between China and Japan]. In: Japanese Studies. No. 2. P. 1-5. (In Chin.)

16. Gao Hong (2020). Ri ben xin guan fei yan yi qing ying dui ji qi dui zhong ri guan xi de ying xiang [Japan's response to the COVID-19 and its impact on China-Japan relations]. In: Japanese Journal. Vol. 2. P. 27-32. (In Chin.)

17. Lin Shengai (2014). Gai ge kai fang zhi chu zhong guo dui han guo "guan min fen li" zheng ce chu tan [A Preliminary Study of China's "Separation of Officials from the People" Policy to South Korea at the Beginning of Reform and Opening-up]. In: Research on Contemporary Chinese History. Vol. 2. P. 68-73. (In Chin.)

18. Liu Tingting (2017). Qian xi kong zi xue yuan gong gong wai jiao zhi neng [A Brief Analysis of the Public Diplomacy Function of Confucius Institutes]. In: Reform and opening, No. 22. P. 139140. (In Chin.)

19. Ministry of Culture and Tourism of the People's Republic of China. (2020). Statistical Yearbook of Chinese Cultural Relics and Tourism. Beijing: National Library Press, 224 p.

Received: 10.09 .2021 .

About author: Liu Xiangqian - postgraduate student of the Department of international relations of the Belarusian state University (Minsk); e-mail: liuxiangqian2016@gmail.com 